\title{
Cheyne-Stokes respiration: poor prognostic sign in a patient with heart failure
}

\author{
Aditya Badheka, Randi Durden, Veerajalandhar Allareddy
}

Department of Pediatrics, University of lowa Stead Family Children's Hospital, lowa City, Iowa, USA

\section{Correspondence to} Dr Aditya Badheka, aditya-badheka@uiowa.edu

Accepted 16 August 2017

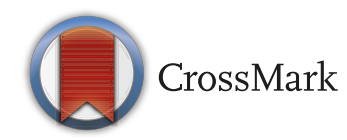

To cite: Badheka $A$, Durden R, Allareddy V. BMJ Case Rep Published Online First: [please include Day Month Year]. doi:10.1136/ bcr-2017-222056

\section{DESCRIPTION}

Patients with congestive heart failure (CHF) have high incidence of sleep-disordered breathing. Two distinct types are known: obstructive sleep apnoea (OSA) and Cheyne-Stokes respiration (CSR). ${ }^{1}$ Effective heart failure treatment improves CSR but not OSA, indicating that the development of CSR is secondary to heart failure. CSR is characterised by recurrent episodes of central apnoea/hypopnoea interposed with periods of hyperpnoea with waning and waxing pattern of tidal volume. A 5-month-old girl who presented with acute onset of poor appetite and tachypnoea had cardiomegaly on chest X-ray. Echocardiography showed severely depressed left ventricular (LV) function with ejection fraction of $10 \%$. She was diagnosed with LV non-compaction cardiomyopathy and placed on heart transplant list. Her heart failure management included milrinone infusion, diuretics and digoxin. She subsequently worsened with increasing heart rate and tachypnoea. Her telemetry showed evidence of CSR with clinical and echocardiographic evidence of worsening LV function (figure 1). She had normal $\mathrm{pH}$ and not receiving any respiratory depressants. Her oxygen saturation varied from $90 \%$ to $100 \%$. The Berlin EXCOR LV assist device was placed with stabilisation of cardiac output. CSR has been commonly observed in acute as well as chronic heart failure with LV systolic dysfunction. The pathophysiology includes hyperventilation from $\mathrm{CHF}$, resulting in a decrease in $\mathrm{P}_{\mathrm{CO} 2}$ below apnoeic threshold, triggering cyclic central apnoea. ${ }^{2}$ The apnoea-hypopnoea index

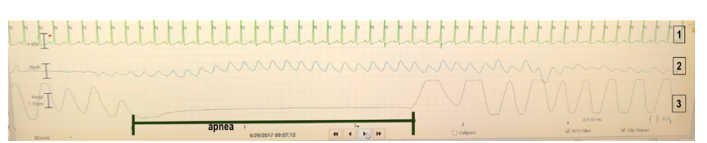

Figure 1 This figure demonstrates central apnoea indicated by a black line. 1: Telemetry showing sinus tachycardia. 2: Plethysmography showing varying amplitude indicative of poor cardiac output. 3: Respiration pattern showing apnoea and hyperpnoea.

\section{Learning points}

- Cheyne-Stokes respiration is characterised by recurrent episodes of central apnoea/ hypopnoea interposed with periods of hyperpnoea with waning and waxing pattern of tidal volume.

- The pathophysiology includes hyperventilation from congestive heart failure, resulting in a decrease in $\mathrm{PCO}_{2}$ below apnoeic threshold, triggering cyclic central apnoea.

- The apnoea-hypopnoea index is defined as the numbers of apnoea and hypopnoea per hour and is an independent predictor of poor prognosis in a clinically stable patient with heart failure.

is defined as the numbers of apnoea and hypopnoea per hour and is an independent predictor of poor prognosis in a clinically stable patient with heart failure. ${ }^{3}$

Contributors $A B, R D$ and $V A$ were responsible for planning, conducting, reporting, conception and design, acquisition, analysis and interpretation of data.

Competing interests None declared.

Provenance and peer review Not commissioned; externally peer reviewed.

(c) BMJ Publishing Group Ltd (unless otherwise stated in the text of the article) 2017. All rights reserved. No commercial use is permitted unless otherwise expressly granted.

\section{REFERENCES}

1 Wang H, Parker JD, Newton GE, et al. Influence of obstructive sleep apnea on mortality in patients with heart failure. J Am Coll Cardiol 2007;49:1625-31

2 Naughton M, Benard D, Tam A, et al. Role of hyperventilation in the pathogenesis of central sleep apneas in patients with congestive heart failure. Am Rev Respir Dis 1993;148:330-8.

3 Lanfranchi PA, Braghiroli A, Bosimini E, et al. Prognostic value of nocturnal Cheyne-Stokes respiration in chronic heart failure. Circulation 1999;99:1435-40. 
Copyright 2017 BMJ Publishing Group. All rights reserved. For permission to reuse any of this content visit http://group.bmj.com/group/rights-licensing/permissions.

BMJ Case Report Fellows may re-use this article for personal use and teaching without any further permission.

Become a Fellow of BMJ Case Reports today and you can:

- Submit as many cases as you like

- Enjoy fast sympathetic peer review and rapid publication of accepted articles

Access all the published articles

- Re-use any of the published material for personal use and teaching without further permission

For information on Institutional Fellowships contact consortiasales@bmjgroup.com

Visit casereports.bmj.com for more articles like this and to become a Fellow 